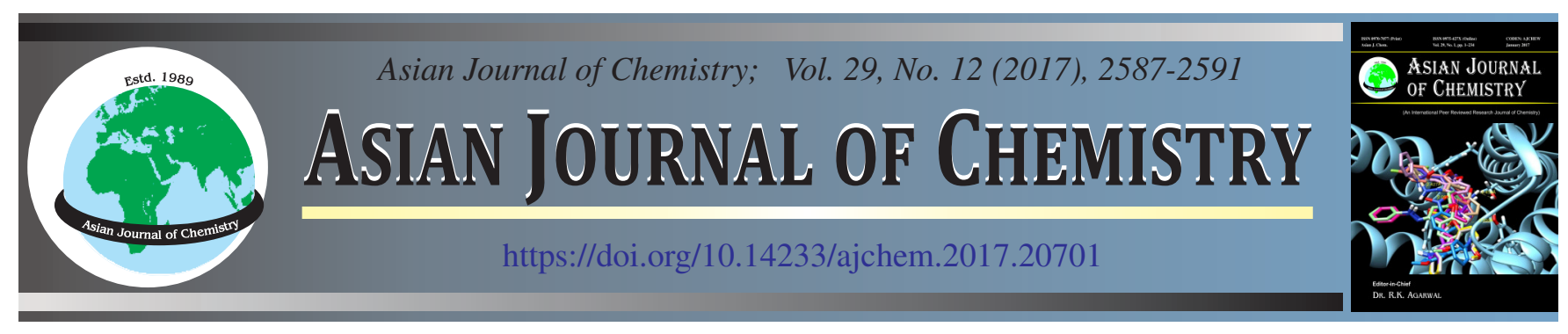

\title{
Chemical Composition, Antioxidant and Myorelaxant Activity of Essential Oil of Hedychium aurantiacum
}

Ravendra Kumar ${ }^{1, *}$, Om Prakash ${ }^{1}$, S.P. Singh ${ }^{2}$, A.K. Pant ${ }^{1}$, Valery A. Isidorov ${ }^{3}$ and Lech SzczePaniak ${ }^{3}$

${ }^{1}$ Department of Chemistry, College of Basic Sciences and Humanities, G.B. Pant University of Agriculture \& Technology, Pantnagar-263 145, U.S. Nagar, India

${ }^{2}$ Department of Pharmacology \& Toxicology, College of Veterinary \& Animal Sciences, G.B. Pant University of Agriculture \& Technology, Pantnagar-263 145, U.S. Nagar, India

${ }^{3}$ Institute of Chemistry, Bialystok University, Division of Environmental Chemistry, UL. Hurtowa 1,15-399, Bialystok, Poland

*Corresponding author: E-mail: ravichemistry.kumar@gmail.com

Received: 11 April 2017;

Accepted: 28 July 2017;

Published online: 30 October 2017;

AJC-18596

\begin{abstract}
Family Zingiberaceae is worldwide in distribution. Plants of this family are used in traditional system of medicine as herbal folk medicine besides its uses in spices, cosmetic, ornamental, food preservatives etc. In Uttarakhand the herbs grow from sub-tropical to temperate region. In present study we worked on Hedychium aurantiacum. The composition of essential oil from the rhizomes of Hedychium aurantiacum was examined by GC and GC-MS techniques. Twenty two constituents representing $97.25 \% .96 .97 \%$ of the oil consisted of monoterpenoids. Sesquiterpenoids were presented only in trace quantities. Linalool $(83.01 \%)$ is the major component of the oil. The other major constituents present in the oil are limonene (4.81\%), $\alpha$-terpinene $(2.69 \%)$, cis-linalool oxide $(1.53 \%)$ and trans-linalool oxide $(1.55 \%)$. The oil showed significant effect significant effect on duodenum smooth muscles of wistar rats and the antioxidant activity of the oil was tested using three different methods viz. Reducing power assay, 2,2-diphenyl-1-picrylhydrazyl (DPPH) assay and effect on of $\mathrm{Fe}^{2+}$ chelating activity. The essential oil of Hedychium aurantiacum showed reducing power activity, 2’2'-diphenyl picryl hydrazyl (DPPH) radical scavenging activity and chelating activity of $\mathrm{Fe}^{2+}$ ions in dose dependent manner but significantly less compared to the standards butylated hydroxyl toluene, gallic acid and catechin.
\end{abstract}

Keywords: Hedychium aurantiacum, GC-MS, Linalool, Zingiberaceae, Antioxidant activity, Duodenum smooth muscles, DPPH. ᄂ - - - - - - - - - - - - - - - - - - - - - - - - - - - -

\section{INTRODUCTION}

The genus Hedychium (Zingiberaceae) contains 50 species distributed in Asia and Madagascar, which grow as herbs with perennial tuberous rootstocks [1]. The genus is well known as a group of medicinal plants. The essential oils can be extracted from leaves, flowers and rhizomes of these plants. It is well documented that these oils have many medicinal efficacies, including cercaricidal properties [2], molluscicidal activity [3], potent inhibitory action with $\mathrm{IC}_{50}$ [4], antimicrobial activities [5-8], in vitro pediculicidal activity [9], anti-inflammatory and analgesic effects [10].

Chemical composition of the essential oil from $H$. aurantiacum [H. coccineum] reported (+)-linalool $(80.6 \%)$ as the main compounds and monoterpene hydrocarbons $(16.0 \%)$. The composition of the oil was markedly different from that of the rhizome essential oil obtained from $H$. spicatum var. acuminatum, a plant which closely resembles $H$. aurantiacum [11]. Chemical composition, antioxidant and antimicrobial properties of the rhizome essential oils of different Hedychium species. H. ellipticum mainly contained 1,8-cineole, sabinene and terpin-4-ol, while $H$. aurantiacum possessed terpin-4-ol, $p$-cymene and bornyl acetate as the major constituents. Similarly, trans-meta-mentha-2,8-diene and linalool were noticed in $H$. coronarium. Three different collections [I (Jageshwar), II (Simla) and III (Bhowali)] of $H$. spicatum showed amazing differences in the relative contents of their essential oils, 1,8-cineole and 10-epi- $\gamma$-eudesmol being identified as markers for samples I and II, terpin-4-ol and sabinene being the major compounds in sample III. The rhizome essential oils of the above species were studied for their antioxidant activities by different methods, including their effect on the chelating properties on $\mathrm{Fe}^{2+}, \mathrm{DPPH}$ radical-scavenging activity and reducing power. Antimicrobial screenings of the oils by the paper-disc method were performed against Staphylococcus aureus, Shigella flexneri, Pasteurella multocida, Escherichia coli and Salmonella enterica enterica and the respective minimum inhibitory concentration (MIC) values were determined. The rhizome essential oils from all 
Hedychium species exhibited moderate-to-good $\mathrm{Fe}^{2+}$ chelating activity. $H$. spicatum from collection site III showed a completely different DPPH radical-scavenging profile than the samples from the other collection sites [12]. A study was conducted to assess the activity of aqueous extracts of Hedychium coronarium rhizome and Zingiber roseum seed and rhizome collected from Kumaun, Uttaranchal, India, on rat duodenal smooth muscle. The extracts of $Z$. roseum seed and $H$. coronarium rhizome relaxed the rat duodenal smooth muscle. A sharp contraction followed by relaxation of the tissue preparation was produced by $Z$. roseum rhizome extract. Propanolol $\left(10^{-6} \mathrm{M}\right)$, a $\beta$-adrenergic receptor blocker, or phenoxybenzamine $\left(10^{-5} \mathrm{M}\right)$, an $\alpha$-adrenergic receptor blocker, could not alter the responses of these extracts. The findings suggest that the extracts contain active principles, which are responsible for the myorelaxant properties on rat duodenal smooth muscle. It also reveals that the responses were not mediated through $\alpha$ - and $\beta$-adrenergic receptors [13].

Plants of the family Zingiberaceae great source of potential chemo therapeutic agent, antimicrobial agent and their ethno medicinal use [14,15], antimicrobial activity [16], antiallergic agent and antiinflammatory agent $[17,18]$, anticancer activity [19-21], antipyretic and analgesic activity [22], anticholinesterase activity [23], antiproliferative activity [24]. The present study was undertaken to study the chemical composition of essential oils from rhizomes of $H$. aurantiacum and assess their antioxidant and myorelaxant activities.

\section{EXPERIMENTAL}

The rhizomes of $H$. aurantiacum were collected from Madhmahashwar located in Garhwal region, Uttarakhand, India. Plant was identified by Dr. D.S. Rawat, plant taxonomist, Department of Biological Sciences of G.B. Pant University of Agriculture \& Technology, Pantnagar, India. The plant specimen has been deposited the department for further reference.

Extraction of essential oil: Essential oil of rhizome studied was obtained by hydrodistillation in a Clevenger-type apparatus for $7 \mathrm{~h}$. The oils were extracted with dichloromethane and dried with anhydrous sodium sulphate and stored at a low temperature.

GC-MS analysis of essential oils: GC-MS analysis was performed on Thermo Quest 2002GC coupled with Finnigan Mat-Polaris Q MS, Detector-MS. The DB-5 column (30 $\mathrm{m} \times$ $0.25 \mathrm{~mm}$ i.d.) with temperature programme $60-210{ }^{\circ} \mathrm{C} @ 3{ }^{\circ} \mathrm{C} /$ min and finally isothermal for $210{ }^{\circ} \mathrm{C}$ and helium as carrier gas with the flow rate of $1 \mathrm{~mL} / \mathrm{min}$, ion source temperature at $200{ }^{\circ} \mathrm{C}$, ion right inlet $210{ }^{\circ} \mathrm{C}$ and MS-transferred at $275^{\circ} \mathrm{C}$. The MS were recorded under EI condition $(70 \mathrm{eV})$ with split mode 40:1. Components were identified by matching their mass spectra with those of NIST-MS Wily Library and comparing the data with literature and GC retention indices [25].

Antioxidant activity: Antioxidant potential of the essential oil was evaluated in terms of 2,2'-diphenyl-1-picrylhydrazyl (DPPH) radical scavenging ability, effect on the chelating activity on $\mathrm{Fe}^{2+}$ and reducing power in comparison with the synthetic and natural antioxidants. Butylated hydroxyl toluene (BHT) was taken as synthetic and catechin, gallic acid as the natural antioxidants.

Reducing power assay: The reducing power of the essential oil was determined by the method reported by Yen $\&$ Duh [26] and Singh et al. [27].
2,2-Diphenyl-1-picrylhydrazyl assay: This scavenging effect on the 2,2-diphenyl-1-picrylhydrazyl (DPPH) radical was determined according to the methods developed earlier [26-28]. DPPH Radical scavenging activity was calculated by following equation.

$$
\text { DPPH radical scavenging activity }(\%)=\left(1-\frac{A_{t}}{A_{o}}\right) \times 100
$$

(where $A_{t}$ is the absorbance of the sample and $A_{0}$ is the absorbance of the control at $517 \mathrm{~nm}$ ).

Effect of the chelating activity on $\mathrm{Fe}^{2+}$ : The chelating activity of essential oils on ferrous ions $\left(\mathrm{Fe}^{2+}\right)$ was measured with slight modification of the method of Decker and Welch [29]. Different amounts of essential oils (5, 10, 15 and $20 \mu \mathrm{L})$ were first mixed in $1 \mathrm{~mL}$ of methanol. Then it was mixed with $3.7 \mathrm{~mL}$ of deionized water. The mixtures were left for reaction with ferrous chloride ( $2 \mathrm{mM}, 0.1 \mathrm{~mL})$ and ferrozine $(5 \mathrm{mM}$, $0.2 \mathrm{~mL}$ ) for $10 \mathrm{~min}$ at room temperature and then absorbance was measured at $562 \mathrm{~nm} \mathrm{UV-spectrophotometer.} \mathrm{A} \mathrm{lower}$ absorbance indicates a higher chelating power. The chelating activity on $\mathrm{Fe}^{2+}$ of the oil was compared with that of EDTA $(0.01 \mathrm{mM})$ and citric acid $(0.025 \mathrm{M})$ and was calculated by following equation:

$$
\text { Chelating activity }(\%)=\left(1-\frac{\mathrm{A}_{\mathrm{t}}}{\mathrm{A}_{\mathrm{o}}}\right) \times 100
$$

(where $A_{t}$ is the absorbance of the sample and $A_{o}$ is the absorbance of the control at $562 \mathrm{~nm}$ ).

\section{Effect of essential oil on duodenum smooth muscles on Wistar rats}

Collection, preparation and mounting of rat duodenum and calibration of physiograph: For the present study on smooth muscles, six healthy adult male Wistar rats, weighing about 150-200 g were procured from, Indian Veterinary Research Institute, Izatnagar, India. After 15 days acclimatization, male rats were anaesthized with chloroform and sacrificed for collecting duodenum. In a petridish containing aerated physiological saline solution (Tyrode solution maintained at $37 \pm 0.5$ ${ }^{\circ} \mathrm{C}$ ). Immediately, the tissues were placed on a filter paper moistened with physiological saline solution and cleaned by removing the connective tissue attached without causing damage to the smooth muscles. A piece of $15 \mathrm{~mm}$ length of duodenum was cut and mounted in an organ bath of $20 \mathrm{~mL}$ capacity containing Tyrode solution ( $\mathrm{pH}$ 7.4) which was continuously bubbled with atmospheric air and maintained at a temperature of $37 \pm 0.5^{\circ} \mathrm{C}$. The tissues were allowed to equilibrate under a constant resting tension of $0.5 \mathrm{~g}$ for a period of $30 \mathrm{~min}$. During equilibration period, the bathing fluid was regularly changed at every $15 \mathrm{~min}$ interval. Isometric contractions were recorded using a force transducer (0-50 g) connected to 4 channel physiograph (Biopac, USA). The scale of the tension was adjusted to $0.5 \mathrm{~g}$. After equilibration period of about $30 \mathrm{~min}$, the drugs were added into the bath fluid and the isometric responses were recorded on 4 channel physiograph.

Preparation of essential oil and drugs: The essential oil of rhizome of $H$. aurantiacum (HRO) was prepared freshly. Acetylcholine, adrenaline, atropine and propranalol were 
freshly prepared in desired concentration and used in the experiments. Dilutions of (1000 and $2000 \mu \mathrm{g})$ of essential oil was prepared in Tyrode solution and ultrasonicated for $10 \mathrm{~min}$ with the help of an ultra-sonicater (Soni Prep, 150, UK) immediately before the use in experiment and were added to the organ bath in an increasing order to record concentration dependent responses, which took about 1-15 min.

Effect of essential oil agonists and antagonists on duodenum smooth muscles: Isolated duodenal tissue of rats exhibited normal motility (peristaltic movements) in Tyrode solution. After equilibration period of $30 \mathrm{~min}$ and before adding any drug the normal motility was recorded for a period of 15 min. Response of Ach (1, 2 and $5 \mu \mathrm{g}$ ) was recorded after providing sufficient rest of 5-10 min to the tissue with repeated intervening washings for at least 2-3 times so that the tissue come to its base line after eliciting the previous response The tissues were allowed to show maximum response to each concentration of the Ach, which took about 1-1.5 min then $100 \mu \mathrm{g}$ atropine was added to the organ bath. The tissues were allowed to show maximum response of the atropine. After the dose of atropine, acetylcholine and essential oil were repeated in same order. Adrenaline ( 1 and $2 \mu \mathrm{g}$ ) was added to the organ bath. The tissues were allowed to show maximum response of the adrenaline, which took about 1-1.5 min. Then test compounds as used in previous concentration were repeated to compare the effect with adrenaline. Then $100 \mu \mathrm{g}$ propranalol was added to the organ bath. The tissues were allowed to show maximum response of the propranalol. After the dose of propranalol, adrenaline and essential oil were repeated in same order.

\section{RESULTS AND DISCUSSION}

Chemical composition: We have earlier reported the chemical composition of $H$. aurantiacum collected from Kumaun region [11]. In our continuing programme to screen the plants of family Zingiberaceae for their bioactive components, the rhizomes of $H$. aurantiacum were collected from Garhwal region (Madmaheswar) at higher elevation compared to earlier collection (approx. $1000 \mathrm{~m}$ ). The analysis of essential oil of the $H$. aurantiacum revealed the presence of 22 compounds. In our earlier investigation, only eight compounds were identified. $\alpha$-Pinene $(1.3 \%)$, camphene $(1.1 \%), \beta$-pinene $(2.5$ $\%)$, myrcene $(1.1 \%)$, car-3-ene $(2.1 \%)$, p-cymene $(0.4 \%)$, limonene $(6.1 \%)$ and linalool $(80.6 \%)$ were identified. The unidentified components were $4.2 \%$.

The rhizome essential oil of $H$. aurantiacum collected from Garhwal region was analyzed by combination of GC and GC/MS. The analysis of the essential oil from rhizome of $H$. aurantiacum resulted in the identification of 22 constituents contributing to $97.3 \%$ of the oil (Table-1). The rhizome oil was found to rich in monoterpenoids, contributing to $97.6 \%$ of the total oil, whereas sesquiterpenoids contributed to only $0.2 \%$ of the oil. Oxygenated monoterpenoids made up the dominant fraction of the oil $(88.1 \%)$. The major compound identified was linalool $(83.01 \%)$. The other major oxygenated hydrocarbons identified in the oil were cis-linalool oxide $(1.53$ $\%$ ) and trans-linalool oxide (1.6\%), which were not identified earlier. The monoterpene hydrocarbons contribute to $8.93 \%$ of the oil. The major constituents were limonene $(4.81 \%)$ and $\alpha$-terpinene $(2.7 \%)$. The oil had low amount of oxygenated sesquiterpenoids contributing to only $0.28 \%$ of the oil which include humulene epoxide II $(0.12 \%), 10$-epi- $\gamma$-eudesmol $(0.16 \%)$. $\alpha$-Copaene and $\beta$-eudesmol were identified in trace amount. Comparison of the results revealed that both the collection of Hedychium aurantiacum are similar in their essential oils. The main chemical marker linalool, which in both cases is more than $80 \%$ of the oil. Some new constituents $\alpha$-terpinene, cis-linalool oxide, trans-linalool oxide, borneol, pinocampheol, terpin-4-ol, $m$-cymene-8-ol, $\alpha$-terpineol, linolyl acetate, bornyl acetate, $\alpha$-copaene, humulene epoxide II, 10epi- $\gamma$-eudesmol and $\gamma$-eudesmol which were not reported earlier were identified during the present investigation.

\begin{tabular}{|c|c|c|c|}
\hline \multicolumn{4}{|c|}{$\begin{array}{c}\text { TABLE-1 } \\
\text { COMPOSITION (\%) OF Hedychium aurantiacum } \\
\text { RHIZOME ESSENTIAL OIL }\end{array}$} \\
\hline $\begin{array}{l}\text { S. } \\
\text { No. }\end{array}$ & Constituent & $\begin{array}{c}\text { Present } \\
\text { investigation }\end{array}$ & $\begin{array}{c}\text { Pant } e t \text { al. } \\
\text { [11] }\end{array}$ \\
\hline 1 & $\alpha$-Thuzene & $\mathrm{t}$ & - \\
\hline 2 & $\alpha$-Pinene & 0.59 & 1.3 \\
\hline 3 & Camphene & $\mathrm{t}$ & 1.1 \\
\hline 4 & Sabinene & $\mathrm{t}$ & - \\
\hline 5 & $\beta$-Pinene & 0.28 & 2.5 \\
\hline 6 & Myrcene & 0.22 & 1.1 \\
\hline 7 & Car-3-ene & - & 2.1 \\
\hline 8 & $\alpha$-Terpinene & 2.69 & - \\
\hline 9 & $p$-Cymene & 0.34 & 0.4 \\
\hline 10 & Limonene & 4.81 & 6.1 \\
\hline 11 & cis-Linalool oxide & 1.53 & - \\
\hline 12 & trans-Linalool oxide & 1.55 & - \\
\hline 13 & Linalool & 83.01 & 80.6 \\
\hline 14 & Borneol & 0.46 & - \\
\hline 15 & Pinocampheol & 0.24 & - \\
\hline 16 & Terpin-4-ol & 0.20 & - \\
\hline 17 & $m$-Cymen-8-ol & 0.15 & - \\
\hline 18 & $\alpha$-Terpineol & 0.34 & - \\
\hline 19 & Linolyl acetate & 0.17 & - \\
\hline 20 & Bornyl acetate & 0.39 & - \\
\hline 21 & $\alpha$-Copaene & $\mathrm{t}$ & - \\
\hline 22 & Humulene epoxide II & 0.12 & - \\
\hline 23 & 10-epi- $\gamma$-eudesmol & 0.16 & - \\
\hline \multirow[t]{7}{*}{24} & $\beta$-eudesmol & $\mathrm{t}$ & - \\
\hline & Unidentified & 2.75 & 4.2 \\
\hline & Total identified & 97.25 & 95.20 \\
\hline & Monoterpene hydrocarbons & 8.93 & 14.3 \\
\hline & Oxygenated monoterpenes & 88.04 & 80.6 \\
\hline & Sesquiterpene hydrocarbons & $\mathrm{t}$ & - \\
\hline & Oxygenated sesquiterpenes & 0.28 & 0.28 \\
\hline
\end{tabular}

\section{Antioxidant activity}

Reducing power activity: The rhizome essential oil from H. aurantiacum was tested for its reducing power and the results are presented in Table-2. The oil possessed significant reducing power activity in dose dependent manner. Maximum activity of the oil was observed at the dose level of $20 \mu \mathrm{L}$ with absorbance $(700 \mathrm{~nm})$ at $1.81 \pm 0.00$ in comparison to that of standard antioxidant BHT $(\mathrm{A}=3.15 \pm 0.00)$.

Radical scavenging activity: 2,2-Diphenylpicryl-hydrazyl (DPPH) radical scavenging activity of the rhizome essential oil was tested in a selected dose levels. The oil exhibited radical 
TABLE-2

REDUCING POWER ACTIVITY OF THE RHIZOME ESSENTIAL OIL OF

Hedychium aurantiacum AT DIFFERENT LEVELS OF CONCENTRATION

\begin{tabular}{ccccc}
\hline Sample & $5 \mu \mathrm{L}$ & $10 \mu \mathrm{L}$ & $15 \mu \mathrm{L}$ & $20 \mu \mathrm{L}$ \\
\hline HARO & $1.479 \pm 0.0007$ & $1.570 \pm 0.0017$ & $1.677 \pm 0.0000$ & $1.809 \pm 0.0000$ \\
(Standard) BHT & $2.106 \pm 0.0007$ & $2.218 \pm 0.0011$ & $2.269 \pm 0.0012$ & $3.147 \pm 0.0008$ \\
Catechin & $4.000 \pm 0.0000$ & $4.000 \pm 0.0000$ & $4.000 \pm 0.0000$ & $4.000 \pm 0.0000$ \\
Gallic acid & $4.000 \pm 0.0000$ & $4.000 \pm 0.0000$ & $4.000 \pm 0.0000$ & $4.000 \pm 0.0000$ \\
\hline (Values are mean \pm standard deviation; $\mathrm{n}=4$ ) & & &
\end{tabular}

scavenging activity in a dose dependent manner. At lower dose level $(5 \mu \mathrm{L})$ the oil exhibited low activity $(13.4 \% \pm 0.03)$ but it increased at higher concentration $(20 \mu \mathrm{L})$ to $20 \% \pm 0.00$ in comparison to the standard antioxidant BHT $(107.6 \% \pm 0.08)$, catechin $(107.8 \% \pm 0.85)$ and gallic acid $(97.84 \% \pm 0.06)$, respectively (Table-3). The results indicates that the oil in free radical scavenger which react with free radicals. It is known that most natural antioxidants after work synergistically to produce a broad spectrum of antioxidative activity that can create an effective defense system against free-radical attack which may be possibly due to different qualitative and quantitative makeup of the constituents present in the oil.

Chelating activity: Solutions of rhizome essential oil in methanol/water were tested at selected doses in the presence of $\mathrm{FeCl}_{2}$ and ferrozine a chelator. The oil showed chelating activity of $\mathrm{Fe}^{2+}$ towards ferrozine in a dose dependent manner. As observed by the change in the UV-visible absorbance of the resulting complex. The highest chelating activity was observed at the concentration of $20 \mu \mathrm{L}(27.43 \% \pm 0.00)$ in comparison to the $0.01 \mathrm{Mm}$ EDTA $(52.07 \% \pm 1.10)$ and $0.025 \mathrm{M}$ citric acid $(47.4 \% \pm 0.41)$.

The results (Table-4) showed that $H$. aurantiacum rhizome essential oil showed good to moderate $\mathrm{Fe}^{2+}$ chelating activity and then could function as $\mathrm{Fe}^{2+}$ chelator and thus could afford protection against oxidative damage.

Linalool a monotrpene alcohol is a component many natural aromatic plants. Linalool has been found to have biological activities including analgesic, anti-inflammatory and antioxidant effects. The anti-inflammatory effects of linalool in lung cells have been associated with modulation of proinflammatory cytokines and antioxidant enzymes. In particular, linalool reduced the levels of nuclear factor-erthroids 2 a regulator of antioxidant stress [30]. In addition linalool found to be effective as an antioxidant in guinea pig brain injected with $\mathrm{H}_{2} \mathrm{O}_{2}$ [31]. One of the major reagents used in antioxidant studies. Also in male wister rates, linalool decreases oxidative stress by modulating malondialdehyde a marker for lipid peroxidation and increased glutathione content [32].

Effect of essential oils agonists and antagonists on duodenum smooth muscles: Oil of rhizome of $H$. aurantiacum (HARO) at the concentrations of $1000 \mu \mathrm{g}$ and $2000 \mu \mathrm{g}$ induced mild to moderate degree of relaxation in quiescent duodenal tissue of rat without any effect on the base line. However, relaxation disappeared within 15-30 min of washing with tyrode solution for 2-3 times. The normal response of duodenal smooth muscles to ACh $(2 \mu \mathrm{g})$ did not alter before and after exposure of the oils and returned to the base line immediately after maximal contraction. Pre-treatment with atropine $(2 \mu \mathrm{g})$ inhibited the ACh induced contraction in duodenal smooth muscles, however, the relaxation induced by the oil (HARO) $2000 \mu \mathrm{g}$ produced same effect as produced before the treatment of atropine. Thus Ach induced tissue response is not blocked by the muscarinic antagonists atropine sulphate but did not alter the effect of the oil by propranalol, (HARO) $2000 \mu \mathrm{g}$ induced relaxation and also did not affect the Ach induced contraction of duodenum smooth muscles. In addition, it was suggested that the oil induced relaxation did not involve acetylcholine receptors.

These observations suggested that the oils did not affect the muscarinic response and activity of ACh of the duodenal smooth muscles. Adrenaline ( 1 and $2 \mu \mathrm{g}$ ) caused relaxation of tissue which returned to base line after 5 min. Treatment of tissue with propranalol $(100 \mu \mathrm{g})$ blocked adrenaline $(2 \mu \mathrm{g})$ induced relaxation but did not affect the relaxation induced by HRO $(1000 \mu \mathrm{g}, 2000 \mu \mathrm{g})$. Persistence of oil induced relaxa-

TABLE-3

PERCENT CHELATING ACTIVITY OF THE ESSENTIAL OILS OF Hedycium auruntiacum AT DIFFERENT LEVELS

\begin{tabular}{|c|c|c|c|c|}
\hline Sample & $5 \mu \mathrm{L}$ & $10 \mu \mathrm{L}$ & $15 \mu \mathrm{L}$ & $20 \mu \mathrm{L}$ \\
\hline HARO & $9.22 \pm 0.121$ & $15.08 \pm 0.003$ & $19.36 \pm 0.001$ & $27.43 \pm 0.002$ \\
\hline (Standard) Citric acid (0.025 M) & \multirow{2}{*}{\multicolumn{4}{|c|}{$\begin{array}{r}47.39 \pm 0.041 \\
52.07 \pm 0.107\end{array}$}} \\
\hline EDTA $(0.01 \mathrm{mM})$ & & & & \\
\hline
\end{tabular}

(Values are Mean \pm Standard deviation; $n=4$ )

\begin{tabular}{ccccc}
\multicolumn{5}{c}{$\begin{array}{c}\text { TABLE-4 } \\
\text { PERCENT DPPH RADICAL SCAVENGING ACTIVITY OF THE RHIZOME } \\
\\
\text { ESSENTIAL OIL OF Hedychium aurantiacum AT DIFFERENT LEVELS }\end{array}$} \\
\hline Sample & $5 \mu \mathrm{L}$ & $10 \mu \mathrm{L}$ & $15 \mu \mathrm{L}$ & $20 \mu \mathrm{L}$ \\
\hline HARO & $13.40 \pm 0.031$ & $16.44 \pm 0.028$ & $18.70 \pm 0.002$ & $19.90 \pm 0.062$ \\
(Standard) BHT & $107.11 \pm 0.078$ & $107.28 \pm 0.055$ & $107.44 \pm 0.159$ & $107.56 \pm 0.081$ \\
Catechin & $106.67 \pm 0.343$ & $107.31 \pm 0.242$ & $107.64 \pm 0.355$ & $107.81 \pm 0.845$ \\
Gallic acid & $96.14 \pm 0.425$ & $96.47 \pm 0.052$ & $97.47 \pm 0.201$ & $97.84 \pm 0.055$ \\
Linoleic acid & $62.92 \pm 0.338$ & $63.50 \pm 0.099$ & $66.08 \pm 0.238$ & $69.03 \pm 1.409$ \\
\hline
\end{tabular}

(Values are mean \pm standard deviation; $\mathrm{n}=4$ ) 
tion after pre-treatment with propranalol suggests that relaxation induced by oil is not mediated through adrenergic receptors.

The primary action of acetylcholine to produce contraction in smooth muscles occurs through muscarinic receptors by causing depolarization of the cell membrane brought about increasing the $\mathrm{Na}^{+}$and $\mathrm{Ca}^{2+}$ conductance [33].

Relaxation of GIT smooth muscles by adrenaline is mediated through $\alpha$ - and $\beta$-adrenergic receptors. Propranalol a non-selective $\beta$-blocker enters sited the adrenaline induced relaxation of GIT smooth muscles [34]. However, propranalol did not block the oil induced duodenal smooth muscles relaxation which suggested that the oil induced relaxation is not mediated through adrenergic receptors. In another study, Bazerra et al. [35] reported GIT smooth muscles relaxation, which was not blocked by adrenergic antagonists. Thus, the effect of adrenergic oil induced relaxation occurs probably due to their inhibitory effect on influx of $\mathrm{Ca}^{2+}$ through cell membrane of rat duodenal smooth muscles.

Linalool has been shown to have presynaptic effects $e x$ vivo upon rat hemidiaphrams stimulated via the phrenic nerve [36]. It also reduces voltage-gated currents of the newt olfactory receptors and retinal horizontal and ganglion cells and voltage gated channel opening in rat cerebellar Purinje cells [37]. Linalool has been shown to act in a concentration dependent manner to decrease compound action potential amplitude of frog and rat sciatic nerves, intact rat dorsal root ganglion neurons and sodium current amplitude of dissociated rat dorsal root ganglion neurons [38]. Proposed mechanism and the opening of presynaptic voltage gated calcium, potassium and sodium channels [37-40].

\section{REFERENCES}

1. K.R. Kirtikar and B.D. Basu, Indian Medicinal Plants, Bishan Singh Mahendra Pal Singh Publishers, New Delhi, vol. 4, 2429 (1975).

2. K.S. Warren and P.A. Peters, Nature, 217, 647 (1968); https://doi.org/10.1038/217647a0.

3. M.M. Saleh, R.M. Kamal and W.A. Abdulla, Planta Med., 45, 166 (1982); https://doi.org/10.1055/s-2007-971366.

4. S. Kumar, K. Ziereis, W. Wiegrebe and K. Muller, J. Ethnopharmacol., 70, 191 (2000);

https://doi.org/10.1016/S0378-8741(00)00203-8.

5. J.R. Medeiros, L.B. Campos, S.C. Mendonca, L.B. Davin and N.G. Lewis, Phytochemistry, 64, 561 (2003); https://doi.org/10.1016/S0031-9422(03)00338-8.

6. G. Gopanraj, M. Dan, S. Shiburaj, M.G. Sethuraman and V. George, Acta Pharm., 55, 315 (2005).

7. G.S. Bisht, A.K. Awasthi and T.N. Dhole, Fitoterapia, 77, 240 (2006); https://doi.org/10.1016/j.fitote.2006.02.004.

8. B. Joy, A. Rajan and E. Abraham, Phytother. Res., 21, 439 (2007); https://doi.org/10.1002/ptr.2091.

9. V. Jadhav, A. Kore and V.J. Kadam, Fitoterapia, 78, 470 (2007); https://doi.org/10.1016/j.fitote.2007.02.016.

10. S. Shrotriya, M.S. Ali, A. Saha, S.C. Bachar and M.S. Islam, Pak. J. Pharm. Sci., 20, 42 (2008).

11. A.K. Pant, C.S. Mathela, V. Dev and A.T. Bottini, J. Essent. Oil Res., 4, 129 (1992);

https://doi.org/10.1080/10412905.1992.9698033.

12. S. Joshi, C.S. Chanotiya, G. Agarwal, O. Prakash, A.K. Pant and C.S. Mathela, Chem. Biodivers., 5, 299 (2008); https://doi.org/10.1002/cbdv.200890027.

13. O. Prakash, M. Rajput, M. Kumar and A.K. Pant, J. Essent. Oil Bearing Plants, 13, 250 (2010); https://doi.org/10.1080/0972060X.2010.10643819.

14. C.P. Kala, J. Ethnobiol. Ethnomed., 1, 11 (2005); https://doi.org/10.1186/1746-4269-1-11.
15. Tushar, S. Basak, G.C. Sarma and L. Rangan, J. Ethnopharmacol., 132, 286 (2010); https://doi.org/10.1016/j.jep.2010.08.032.

16. A. Martins, L. Salgueiro, M. Gonçalves, A. Cunha, R. Vila, S. Cañigueral, V. Mazzoni, F. Tomi and J. Casanova, Planta Med., 67, 580 (2001); https://doi.org/10.1055/s-2001-16494.

17. S. Tewtrakul and S. Subhadhirasakul, J. Ethnopharmacol., 109, 535 (2007); https://doi.org/10.1016/j.jep.2006.08.010.

18. N.S. Mashadi, R. Ghiasvand, G. Askari, M. Hariri, L. Darvishi and M.R. Mfid, Int. J. Prev. Med., 1, S1 (2013).

19. C. Kirana, I.R. Record, G.H. McIntosh and G.P. Jones, Pharm. Biol., 41, 271 (2003); https://doi.org/10.1076/phbi.41.4.271.15673.

20. Y. Cai, Q. Luo, M. Sun and H. Corke, Life Sci., 74, 2157 (2004); https://doi.org/10.1016/j.1fs.2003.09.047.

21. D.M. Sakarkar and V.N. Deshmukh, Int. J. Pharm. Tech. Res., 3, 298 (2011).

22. A. Zuraini, M.N. Somchit, M.H.N. Shukriyah and A.A. Bustamam, Int. J. Pharmacol., 1, 277 (2005); https://doi.org/10.3923/ijp.2005.277.280.

23. S. Okonogi and W. Chaiyana, Drug Discov. Ther, 6, 249 (2012).

24. S.C. Kang, C.M. Lee, H. Choi, J.H. Lee, J.S. Oh, J.H. Kwak and O.P. Zee, Phytother. Res., 20, 1017 (2006); https://doi.org/10.1002/ptr.1987.

25. R.P. Adams, Identification of Essential Oil Components by Gas Chromatography, Mass Spectrometry, Allured Publishing Corporation, Carol Stream, Illinois, USA (1995).

26. C.G. Yen and P.D. Duh, J. Am. Oil Chem. Soc., 70, 383 (1993); https://doi.org/10.1007/BF02552711.

27. G. Singh, P. Marimuthu, H.S. Murali and A.S. Bawa, J. Food Saf., 25, 130 (2005); https://doi.org/10.1111/j.1745-4565.2005.00564.x.

28. M. Cuendet, K. Hostettmann, O. Potterat and W. Dyatmiko, Helv. Chim. Acta, 80, 1144 (1997); https://doi.org/10.1002/hlca.19970800411.

29. E.A. Decker and B. Welch, J. Agric. Food Chem., 38, 674 (1990); https://doi.org/10.1021/jf00093a019.

30. Q. Wu, L. Yu, J. Qiu, B. Shen, D. Wang, L.W. Soromou and H. Feng, Int. Immunopharmacol., 21, 456 (2014); https://doi.org/10.1016/j.intimp.2014.05.030.

31. S. Celik and A. Ozkaya, J. Biochem. Mol. Biol., 35, 547 (2002).

32. S. Mehri, M.A. Meshki and H. Hosseinzadeh, Drug Chem. Toxicol., 38, 162 (2015); https://doi.org/10.3109/01480545.2014.919585.

33. B.B. Hoffman and P. Taylor, in eds.: J.G. Hardman, L.E. Limbird, P.B. Molinoff and A.G. Gilman, Neurotransmission: The Autonomic and Somatic Motor Nervous System, In: Goodman \& Gilman's the Pharmacological Basis of Therapeutics,. McGraw-Hill, New York, pp. 115-153 (2001).

34. D.J. Hoffman, in eds.: J.G. Hardman and L.E. Limbird, Catecholamines, Sympathomimetic Drugs and Adrenergic Receptor Antagonists, In: Goodman \& Gilman's The Pharmacological Basis of Therapeutics, McGraw-Hill Book Company, New York, pp. 215-268 (2001).

35. M.A.C. Bezerra, J.H. Leal-Cardoso, A.N. Coelho-de-Souza, D.N. Criddle and M.C. Fonteles, Phytother. Res., 14, 549 (2000); https://doi.org/10.1002/1099-1573(200011)14:7<549::AIDPTR623>3.0.CO;2-T.

36. C. Ghelardini, N. Galeotti, G. Salvatore and G. Mazzanti, Planta Med., 65, 700 (1999); https://doi.org/10.1055/s-1999-14045.

37. K. Narusuye, F. Kawai, K. Matsuzaki and E. Miyachi, J. Neural Transm., 112, 193 (2005); https://doi.org/10.1007/s00702-004-0187-y.

38. I. Zalachoras, A. Kagiava, D. Vokou and G. Theophilidis, Planta Med., 76, 1647 (2010); https://doi.org/10.1055/s-0030-1249956.

39. A. Prashar, I.C. Locke and C.S. Evans, Cell Prolif., 37, 221 (2004); https://doi.org/10.1111/j.1365-2184.2004.00307.x.

40. A. Khan, A. Ahmad, F. Akhtar, S. Yousuf, I. Xess, L.A. Khan and N. Manzoor, Res. Microbiol., 161, 816 (2010); https://doi.org/10.1016/j.resmic.2010.09.008. 